\title{
THE EFFECT OF DENSITY TO THE SURVIVAL RATE, GROWTH AND BIOCHEMICAL COMPOSITION OF FEMALE MANGROVE CRAB (SCYLLA OLIVACEA) CULTIVATED WITH SILVOFISHERY SYSTEM
}

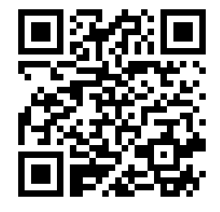

\author{
Muhammad Yusri Karim *1 ${ }^{*}$, Khairul Amri 1, Hasni Yulianti Azis 1, Nurfadilah 2, \\ Alimuddin ${ }^{3}$, Zainal Usman ${ }^{4}$ \\ ${ }^{* 1}$ Faculty of Marine Sciences and Fisheries, Hasanuddin University, Makassar, Indonesia \\ 2 Faculty of Fisheries, Cokroaminoto University, Makassar, Indonesia \\ ${ }^{3}$ State Agricultural Polytechnic, Pangkep, Indonesia \\ ${ }^{4}$ Polytechnic of Marine and Fisheries, Bone, Indonesia
}

DOI: https://doi.org/10.29121/granthaalayah.v8.i6.2020.293

Article Type: Research Article

Article Citation: Muhammad Yusri Karim, Khairul Amri, Hasni Yulianti Azis, Nurfadilah, Alimuddin, and Zainal Usman. (2020). THE EFFECT OF DENSITY TO THE SURVIVAL RATE, GROWTH AND BIOCHEMICAL COMPOSITION OF FEMALE MANGROVE CRAB (SCYLLA OLIVACEA) CULTIVATED WITH SILVOFISHERY SYSTEM. International Journal of Research GRANTHAALAYAH, 8(6), 20-25. https://doi.org/10.29121/granthaa layah.v8.i6.2020.293

Received Date: 01 May 2020

Accepted Date: 20 June 2020

Keywords:

Female Mangrove Crabs

Growth

Survival

Body Chemical Composition

\begin{abstract}
Mangrove crab silvofishery system is one of the potential aquaculture activities to be developed because it is supported by the availability of extensive mangrove areas. This research was carried out in the Mangrove Area of Mandalle Village, Pangkep Regency, South Sulawesi. The study was aimed to determine the best density of survival, growth, and chemical composition of the body of female mangrove crabs (Scylla olivacea) maintained by the silvofishery system. The research container used a step cage made of bamboo measuring $2.25 \mathrm{~m} 2$ wide. Tested animals used were female mangrove crabs measuring $155 \pm 1.0 \mathrm{~g}$ which were kept for 40 days. The study was designed using a randomized block design consisting of four density treatments with three replications each. The four densities were: $5,10,15$ and 20 crabs/cage. The results of the analysis of variance showed that the difference in density has a very significant effect $(p<0.01)$ on the survival, growth and biochemical composition of the female body of mangrove crabs. The best survival, growth, and biochemical composition produced the best density of 5 and 10 individuals, while the lowest density was 20 individuals.
\end{abstract}

\section{INTRODUCTION}

Mangroves are one of the ecosystems in coastal areas which are used as habitats for various terrestrial and marine organisms (mammals and amphibians) such as crabs, shrimp, fish, and so forth. Mangrove forest ecosystems have important ecological, economic and social functions in development, especially in coastal areas (Sambu et al., 2014; Awn et al., 2016). Economically, mangrove forests can be used sustainably for building materials, charcoal, and pulp. In addition, mangrove ecosystems can also be used as tourist attractions, research and education.

(C) 2020 The Author(s). This is an open access article distributed under the terms of the Creative Commons Attribution License, which permits unrestricted use, distribution, and reproduction in any medium, provided the original author and source are credited. 
The Effect of Density to The Survival Rate, Growth and Biochemical Composition of Female Mangrove Crab (Scylla Olivacea) Cultivated with Silvofishery System

Interaction between the components makes the mangrove ecosystem as a good habitat for various types of biota. In addition to its tidal and fertile conditions that support, mangroves have the potential to be developed into aquaculture areas. This fact is often found in mangrove lands that have been converted into ponds. The activity of transforming the natural function of mangroves into fishponds (economic functions) often does not pay attention to aspects of sustainability and feasibility. The result is a decrease in environmental quality such as: an increase in the rate of sedimentation, decay of organic matter and the threat of various types of fauna inhabiting mangroves due to ecological changes (Chacraborty, 2018; Wamnebo et al., 2018). By considering various mangrove functions, efforts to convert into aquaculture must be considered and carried out rationally with an environmental perspective. Thus, it is necessary to implement a system that can guarantee both interests, one of which is aquaculture with a silvofishery system.

Silvofishery is one of the models of aquaculture activities in mangrove areas. The basic principle of the aquaculture system is the multiple or multiple uses of the existence of mangroves without eliminating the function of the ecosystem naturally, so that fishery and mangrove products are obtained which can still play a biological, ecological and economic function (Susilo et al., 2018; Asriani et al., 2019; Karim et al. 2019).

Various species of aquatic biota that may be cultivated with silvofishery systems, one of them is mangrove crabs. Mangrove crab is an important economically valuable fishery commodity, has high nutritional value, and is preferred by consumers. Mangrove crabs have been known both in the domestic and foreign markets because of the delicious taste of meat and high nutritional value. Based on the results of proximate analysis it is known that mangrove crab meat contains $44.85-50.58 \%$ protein, fat $10.52-13.08 \%$ and energy $3579-3.724 \mathrm{kcal} / \mathrm{g}$. In addition, crab meat contains various important nutrients such as minerals and $\varpi-3$ fatty acids. Even though crab meat contains cholesterol, it has low saturated fat content. Crab is also a source of protein, niacin, folate, potassium, vitamin B12, phosphorus, zinc, copper and selenium (Karim, 2013).

The cultivation of mangrove crab with silvofishery systems in mangrove areas may be done using step cages. Several studies on the cultivation of mangrove crab with silvofishery systems in the mangrove area have been carried out by Karim et al. (2016 and 2017), Wamnebo et al. (2018), Karim et al. (2019), and Asriani et al. (2019). In all of these studies using male crabs, while research on the cultivation of mangrove crab silvofishery systems using female crabs has not been available yet. It is hypothesised that the growth and biochemical composition between male and female crabs are different. Therefore, information about the survival and growth rates of female mangrove crabs that are maintained by the silvofishery system needs to be studied in the context of developing mangrove crabs. This study was aimed to determine the best density of survival, growth, and biochemical composition of female mangrove crabs (S. olivacea) which are maintained by the silvofishery system.

\section{RESEARCH METHODS}

The study was conducted in the mangrove area of Mandalle Village, Mandalle District, Pangkep Regency, South Sulawesi Province, Indonesia. Proximate analysis of crabs and water quality in the form of ammonia and nitrite was carried out at the Aquaculture Laboratory of Pangkep State Agricultural Polytechnic.

The research container used a step cage made of bamboo measuring $2.25 \mathrm{~m} 2$ wide which was placed in the mangrove area. The outer part of the cage was covered with waring (plastic ropes) which aims to protect the cage from the rubbish and dirt carried by the waves. The feed used was trash fish in the form of chopped tilapia fish. Feeding was done once a day i.e in the afternoon at $5 \mathrm{pm}$ with a dose of $10 \%$ of crab biomass. To keep the water circulation in the cages running smoothly, the bamboo cleavage between one and the other was given a distance of about $1 \mathrm{~cm}$. To keep dirt and rubbish from sticking to waring, the waring was replaced every day.

Tested animals used were female mangrove crabs (S. olivacea) measuring $155 \pm 1.0 \mathrm{~g}$. The crabs were obtained from crab collectors in Pallime Village, Cenrana District, Bone Regency, South Sulawesi and kept for 40 days. Before the crab was stocked into confinement it was first adapted to the condition of the maintenance environment for two days. During the adaptation period, crabs were fed in the form of chopped Tilapia fish ad libitum. Before the crab was stocked into a research container, first the weight was selected by weighing using a $1.0 \mathrm{~g}$ digital sitting scale.

The study was designed using a Randomized Block Design (RBD) consisting of four treatments with three replications each so that the study consisted of 12 experimental units. The four types of treatments that were tested were differences in crab density, namely 5, 10, 15, and 20 animals/cage. 
Muhammad Yusri Karim, Khairul Amri, Hasni Yulianti Azis, Nurfadilah, Alimuddin, and Zainal Usman

The parameters observed in this study were survival rate, absolute growth, and crab body chemical composition.

Survival rate was calculated using the following formula:

$$
\mathrm{SR}=\mathrm{Nt} / \mathrm{No}
$$

Note: $\mathrm{S}$ is survival rate (\%), Nt is the number of live crabs at the end of the study, and No is the number of crabs at the beginning of the study.

The absolute growth of crabs was calculated using the following formula:

$$
\mathrm{W}=\mathrm{Wt}-\mathrm{Wo}
$$

Note: $\mathrm{W}$ is the absolute growth of mangrove crabs (g), Wo is the average crab weight at the beginning of the study (g), and $\mathrm{Wt}=$ the average crab weight at the end of the study (g).

The chemical composition of the body measured was protein, fat, and energy. Protein was analyzed using the Kjedal Method, fat with the Soxlet Method, and energy using a Calorimeter Bomb. The analysis was performed using the AOAC Procedure (2016).

As supporting data, during the research, several physical and chemical parameters of the water environment of crab maintenance were measured, including: temperature, salinity, $\mathrm{pH}$, dissolved oxygen, ammonia, and nitrite. Temperature, salinity, $\mathrm{pH}$, and dissolved oxygen were measured twice a day i.e in the morning (6 am) and the afternoon $(5 \mathrm{pm})$. The ammonia and nitrite were measured three times during the study, namely at the beginning, middle and end of the study.

Research data were analyzed using Analysis of Variance and W-Tuckey follow-up Tests.

\section{RESULTS AND DISCUSSION}

\subsection{SURVIVAL AND GROWTH RATES}

The average survival and growth rates of female mangrove crabs maintained by silvofishery systems with various densities were presented in Table 1.

Table 1: Average survival and growth of female mangrove crabs maintained silvofishery systems with various densities

\begin{tabular}{|c|c|c|}
\hline Density (Individuals) & Survival Rate (\%) & Absolute Growth (g) \\
\hline 5 & $93.33 \pm 11.55^{\mathrm{a}}$ & $49.25 \pm 7.38^{\mathrm{a}}$ \\
10 & $93.33 \pm 5.48^{\mathrm{a}}$ & $43.42 \pm 1.63^{\mathrm{ab}}$ \\
15 & $68.89 \pm 3.84^{\mathrm{b}}$ & $36.85 \pm 2.04^{\mathrm{b}}$ \\
20 & $65.00 \pm 8.66^{\mathrm{b}}$ & $30.81 \pm 3.29^{\mathrm{c}}$ \\
\hline
\end{tabular}

Note: different letters in the same column show a significant difference $(\mathrm{P}<0.05)$ between treatments at $5 \%$ level $(\mathrm{p}<0.05)$

The results of the Analysis of Variance showed that the difference in density had a very significant effect (p $<0.01$ ) on the survival and growth of female mangrove crabs maintained by the silvofishery system. W-Tuckey's further test results showed that the survival and growth rates of female mangrove crabs with densities of 5 and 10 animals/cage did not show significant differences ( $p>0.05)$, but were significantly different $(p<0.05)$ with densities of 15 and 20 animals/cages. Survival and growth rates of the best female mangrove crabs were produced at densities of 5 and 10 animals/cages while the lowest was at 20 animals/cage.

Based on Table 1 above, it may be observed that the survival and growth rates of the best female mangrove crabs were produced at densities of 5 and 10 animals/cage, and the lowest in 20 animals/cages. This showed that the density of 5-10 animals/cage was the best density for female mangrove crabs that were maintained by a silvofishery system. Increased crab density to 15 to 20 animals/cage results in lower survival and growth rates. This is due to the high density that may increase competition for food and living space among crabs. Overcrowding density caused different kinds of death, as a result of cannibalism (Chang, 1997; Chakraborty, 2018). If the cage used is too narrow compared to the number of crabs stocked, it may cause accumulation of crabs with each other, consequently 
The Effect of Density to The Survival Rate, Growth and Biochemical Composition of Female Mangrove Crab (Scylla Olivacea) Cultivated with Silvofishery System

there will be competition between places and stress. The survival rate obtained in this study ranged from 65.00 to 93.33\%. Some research results about the survival of mangrove crabs include Begum et al. (2009) obtained survival rates of 86.25-93.75\%, Mirera and Mtile (2009) 35.0-61.5\%, Karim et al. (2017) 61.67-93.33\% and Karim et al (2019) 53.33-96.67\%.

Density is one of the factors that influence the behavior, growth and production of crabs. Therefore, maximum growth can only be obtained if crabs are kept at the right stocking density (Trino et al., 1999; Shakir et al., 2010). The absolute growth of low-grade female crabs with a density of 20 animals/cage as a result of the influence of high density causes competition in getting food and space between individuals. In addition, high density causes the formation of a size hierarchy, or even social hierarchy which ultimately affects the variation of growth. High density and social hierarchy stimulate neuroendocrine in the central nervous system axis, thereby increasing plasma cortisol or the hormone hyperglycemia which is one indicator of stress. Stressfulness can stimulate the subdominal endocrine system of individuals which in turn accelerates energy consumption, changes the energy supply and ultimately plays a negative role in growth.

\subsection{BIOCHEMICAL COMPOSITION OF CRAB BODY}

The biochemical composition of female mangrove crabs that were maintained by a silvofishery system with various densities was presented in Table 2 .

Table 2: Biochemical composition of female mangrove crab bodies maintained with silvofishery systems with various densities

\begin{tabular}{|c|c|c|c|}
\hline Density (Individual) & \multicolumn{3}{|c|}{ Density (Individual) } \\
\cline { 2 - 4 } & Density (Individual) & Fat (\%) & Energy (Kcal/g) \\
\hline 5 & $48.26 \pm 0.07^{\mathrm{a}}$ & $12.15 \pm 0.11^{\mathrm{a}}$ & $3.668 \pm 13,05^{\mathrm{a}}$ \\
10 & $48.06 \pm 0.23^{\mathrm{a}}$ & $12.04 \pm 0.08^{\mathrm{a}}$ & $3.632 \pm 225^{\mathrm{a}}$ \\
15 & $46.43 \pm 0.40^{\mathrm{b}}$ & $10.95 \pm 0.08^{\mathrm{b}}$ & $3.510 \pm 14,05^{\mathrm{b}}$ \\
20 & $44.97 \pm 7.70^{\mathrm{c}}$ & $10.33 \pm 0.12^{\mathrm{c}}$ & $3.405 \pm 5,69^{\mathrm{c}}$ \\
\hline
\end{tabular}

Remarks: different letters indicate significant differences between treatments at the $5 \%$ level $(p<0.05)$

The results of the Analysis of Variance showed that the difference in density had a very significant effect (P $<0.01$ ) on the protein content, fat, and energy of the female mangrove crabs that were maintained by the silvofishery system. Furthermore, the results of W-Tuckey's further tests showed that the content of protein, fat, and energy of female mangrove crabs maintained with densities of 5 and 10 animals/cage did not show any significant difference ( $p>0.05$ ), but differed significantly with densities of 15 and 20 animals/cage. The best content of protein, fat and energy of female mangrove crabs was produced at the densities of 5 and 10 animals/cage while the lowest was at 20 animals/cage.

Based on Table 2, it may be indicated that the highest protein and fat content of female mangrove crabs was produced at a density of 5 individuals/cage, but did not show any significant difference with the density of 10 individuals/cage, while the lowest protein and fat content at 20 animals/cage. The density of crabs of 5 and 10 individuals/cage was thought to still be able to create comfortable conditions for fellow crabs because competition in getting feed and wider space so that cannibalism and social hierarchy and opportunities for stress were lower. Thus, the use of energy to deal with stress was lower so that the accumulation of the material increases and ultimately increases the growth of crabs. Protein content and crab fat was lower at densities of 15 and 20 animals/cage thought to be due to stress density. Crabs in stress conditions will use a number of nutrients from the tissue so that the nutrient content decreases. This shows that the density of crab anabolic influence in the form of protein and fat synthesis in the body of the crab. High protein and fat content was one indicator of increased growth (Whiteley et al., 2001). The change in the percentage of protein and fat in each density indicates the use of protein and fat, as an energy source and the formation of body tissues (Piliang and Djojosoebagiao, 2006). The main function of protein is as a substance for building body tissues, while fat as a component of the cells to function as a source of energy and is a factor in the synthesis of cholesterol and acts as body fat as an insulator and protector of important organs. 
Muhammad Yusri Karim, Khairul Amri, Hasni Yulianti Azis, Nurfadilah, Alimuddin, and Zainal Usman

The difference in protein and fat content influences the crab energy content. Based on Table 2 it appears that the higher the protein content and crab fat, the higher the energy content, and vice versa. The results of this study indicate that the average energy content of mangrove crabs that are maintained with the highest density of 5 animals/cage was $3.668 \mathrm{kcal} / \mathrm{g}$ while the lowest was at 20 animals/cage which was $3.405 \mathrm{kcal} / \mathrm{g}$. The difference in crab body chemical composition in the form of protein, fat, and energy influences the absolute growth of mangrove crabs. The higher the body's nutrient content, the faster its growth. This can be seen from the absolute growth of crabs (Table 1) where the highest absolute growth of crabs in crabs maintained with a density of 5 animals/cage although not significantly different from the density of 10 individuals/cage. Availability

\subsection{WATER QUALITY}

During the research, the physical and chemical parameters of the environmental maintenance of mangrove crabs were measured. The values for the range of physical and chemical parameters in the environment of mangrove crab maintenance during the study were presented in Table 3

Table 3: The values of the range of water quality values for the environmental maintenance of crabs during the study

\begin{tabular}{|l|c|}
\hline Parameter & Range Values \\
\hline Temperature $\left({ }^{\circ} \mathrm{C}\right)$ & $25-29$ \\
Salinity & $15-27$ \\
pH & $7.53-7.95$ \\
Dissolved Oxygen (ppt) & $3.15-4.91$ \\
Ammonia (ppm) & $0.004-0.012$ \\
Nitrite (ppm) & $0.22-0.37$ \\
\hline
\end{tabular}

Based on Table 3 above, the environmental temperature of crab rearing during the study ranges from $25-29^{\circ} \mathrm{C}$, salinity 15 - 27 ppt, pH 7.53 - 7.95, dissolved oxygen 3.15-4.91 ppm, ammonia 0.004-0.012 ppm, and nitrite 0.22 $0.37 \mathrm{ppm}$. These value ranges are appropriate to support the life of mangrove crabs. The optimum temperature for growth of mangrove crabs is $26-32{ }^{\circ} \mathrm{C}$, salinity $15-30 \mathrm{ppt}$, pH $7.0-8.5$; dissolved oxygen $>3 \mathrm{ppm}$, ammonia $<0.1$ ppm and nitrite < 0.5 ppm (Christensen et al., 2005; Karim, 2013).

\section{CONCLUSION}

Based on this study it is concluded that the density of 5 to 10 animals/cage produced survival rate, growth rate, and biochemical composition of the best female mangrove crabs that were maintained by the silvofishery system

\section{SOURCES OF FUNDING}

None.

\section{CONFLICT OF INTEREST}

None.

\section{ACKNOWLEDGMENT}

None.

\section{REFERENCES}

[1] AOAC. 2016. Official Methods of Analysis of The Association of Official Analytical Chemists. 21 th eds. Association of Official Analytical Chemists. Arlington VA. 
The Effect of Density to The Survival Rate, Growth and Biochemical Composition of Female Mangrove Crab (Scylla Olivacea) Cultivated with Silvofishery System

[2] Asriani, M. Y. Karim, and H. Y. Azis. 2019. Study of Mud Crab (Scylla olivacea) Growth Which Cultivated In Silvofishery System In Various Types Of Mangrove Vegetation. International Journal of Scientific and Research Publications, Volume 9, Issue 2: 376-381.

[3] Awn M. S. M., F. Yulianda F, and Yonvitne. 2016 Characteristics and Above-Ground Biomass of Mangrove Species in Enggano Island, Bengkulu, Sumatra, Indonesia. International Journal of Advanced Engineering, Management and Science 2(7):1084-1091.

[4] Begum, M., Shah M.M.R., Mamun A.A., Alam, M.J. 2009. Comparative Study of Mud Crab (Scylla serrata) Fattening Practices Between Two Different Systems in Bangladesh. J. Bangladesh Agril. Univ. 7 (1): 151-156.

[5] Chakraborty, B.K. 2018. Effect of Stocking Density on Survival, Growth and Production of Mud Crab Juvenile by Pen Culture System of Bangladesh. International Journal of Oceanography \& Aquaculture. Volume 2, Issue 4: 1-11.

[6] Chang WW (1997) Pen Culture of Mud Crabs In The Mangrove Ecosystems In Sarawak (East Malaysia). Aqua Asia II, pp: 3-5.

[7] Christensen, S. M., D.J. Macintosh, and N. T. Phuong. 2005. Pond Production of The Mud Crab Scylla paramamosain (Estampador) and S. olivacea (Herbst) in The Mekong Delta, Vietnam, Using Two Different Supplementary Diets. Aqua. Res., 35: 1013-1024.

[8] Karim, M, Y. 2013. Mangrove Crab (Scylla sp.) (Bioecology, Cultivation and Hatchery). Yarsif Watampone, Jakarta.

[9] Karim, M. Y., H. Y. Azis, Muslimin, and A. M. Tahya. 2017. Physiological Response: Survival, Growth, and Nutrient Content of The Mud Crabs (Scylla olivacea) Which Cultivated In Mangrove Area With Different Types of Feed. ACCL Bioflux, Vol. 10 Issue 6, pp: 1534-1539.

[10] Karim, M. Y., H. Y. Azis, K. Amri, Nurfadilah, Alimuddin, Muslimin, and Anton. 2019. Fattening of Mangrove Crab (Scylla olivacea) By Silvofishery System with Different Feeding Frequency. International Journal of Scientific and Research Publications, Volume 9, Issue 3: 53-57.

[11] Kim, J.D. and S.P. Lall. 2001. Effect of Dietary Protein Level on Growth and Utilization of Protein and Energy by Juvenile Haddock (Melanogrammus aeglefinus). Aquaculture 195: 311-319.

[12] Marichamy, R. and S. Rajapackiam. 2001. The Aquaculture of Scylla Species in India. Asian Fisheries Science, 14: 231-238.

[13] Pedapoli S., and K. R. Ramudu. 2014. Effect of Water Quality Parameters on Growth and Survivability of Mud Crab (Scylla tranquebarica) in Grow Out Culture at Kakinada Coast, Andhra Pradesh. International Journal of Fisheries and Aquatic Studies 2(2): 163-166.

[14] Piliang, W.G. and S. Djojosoebagio. 2006. Nutrition Physiology. Volume 2. Bogor Agriculture University Press, Bogor.

[15] Rosa, R. \& Nunes, M. L. 2003. Biochemical Composition of Deep-Seadecapods Crustaceans with Two Different Benthic Life Strategies of the Portuguese South Coast. Deep-sea Res. 50: 119-130.

[16] Sambu A. H., Rahmi R., Khaeriyah A., 2014 Analysis of Characteristics of and Use Value of Mangrove Ecosystem (Case study in Samataring and Tongketongke Sub-Districts, Sinjai Regency). Journal of Environment and Ecology, 5(2):222-233.

[17] Shakir C, Amanilal A, Jayakumari M, Sujith S, Selvin J. 2010. Current Status of Shrimp Farming in The Southwestern Coast (Manroe Island, Kollam) of India. Iranica J Ener Environ.1:287-292.

[18] Tahya, A. M. 2016. Mandibular Organ Study and Its Utilization As Molting Stimulant of Mud Crab Scylla olivacea. Bogor Agricultural University, Bogor, Indonesia. (Ph.D Thesis).

[19] Trino, A.T., O.M. Millamena, and C. Keenan. 1999. Commercial evaluation of monosex pond culture of the mud crab Scylla species at three stocking densities in the Philippines. Aquaculture, Volume 174, Issue 1-2:109-118.

[20] Wamnebo, M. I., A. Niartiningsih, and M. Y. Karim. 2018. A Study of Mangrove Crab (Scylla serrata) Aquaculture Cultivated by Means of Silvofishery Method with Different Doses of Waste Fish Feed. Global Journal of Science Frontier Research: E Marine Science, Volume 18, Issue 1: 60-63.

[21] Whiteley, N.M., F.R. Robertson, J. Meagor, A.J. El Haj, and E.W. Taylor. 2001. Protein Synthesis and Specific Dynamic Action in Crustaceans: Effect of Temperature. Comp Biochem Physiol 128A: 595-606. 